九州大学学術情報リポジトリ

Kyushu University Institutional Repository

Estimation of Water Requirement for Each Area and Actual Water Allocation: Referring to the Thai land Gravity Irrigation District (3)

Fukuda, Tetsuro

Faculty of Agriculture, Gradute School, Kyushu University

https://doi.org/10.5109/4697

出版情報：九州大学大学院農学研究院紀要. 50 (2)，pp.889-897，2005-10-01. Faculty of Agriculture, Kyushu University

バージョン：

権利関係 : 


\title{
Estimation of Water Requirement for Each Area and Actual Water Allocation -Referring to the Thailand gravity irrigation district (3)-
}

\author{
Tetsuro FUKUDA* \\ Laboratory of Irrigation and Water Utilization, Division of Regional Environment Science, \\ Department of Bioproduction Environmental Sciences, Faculty of Agriculture, \\ Graduate School, Kyushu University, Fukuoka 812-8581, Japan \\ (Received July 15, 2005 and accepted July 26, 2005)
}

\begin{abstract}
In the previous report, a water demand estimation model in upland field and paddy field was developed. In this paper, water demand of whole district where upland field and paddy field, etc. intermingle, namely the technique of water requirement estimation of the whole district, is developed.

As the result, that reuse of water ratio was $10-20 \%$ by comparing a water demand by the simulation with actual water supply; almost clarified. Developed gross water requirement estimation model had the good reproducibility.
\end{abstract}

\section{INTRODUCTION}

In the previous report, a water demand estimation model in upland field and paddy field was developed. In this paper, water demand of whole district where upland field and paddy field, etc. intermingle, namely the technique of water requirement estimation of the whole district, is developed. And, a water demand calculated by this technique is compared with actual water supply, and the model is verified.

The object region of district water requirement estimation is Sam Chuk of the Thailand gravity irrigation district. In this paper, Section 1 of the inside is analyzed as example.

By the method for developing in the previous report, irrigation water is calculated to the every crop. Gross water requirement $\left(\mathrm{m}^{3} / \mathrm{d}\right)$ is obtained by multiplying the planted area in this. Gross water requirement of the whole district is obtained by totaling gross water requirement of the every crop. The gross water requirement is water demand which is necessary in the whole district. Actually, though the irrigation efficiency should be introduced considering conveyance loss of canal, etc., it is 1.0 this time, the efficiency shall estimate it.

\section{PLANTING AREA TOTALING}

It is convenient for the water management, if water demand is calculated, in making the block in which a check of water supply is possible to be a unit. In the regulator site, water level and gate opening, are observed. It is possible to calculate discharge from the record of water level and gate opening. Therefore, we shall calculate water demand in

* Corresponding author (E-mail: tfukuda@bpes.kyushu-u.ac.jp) 


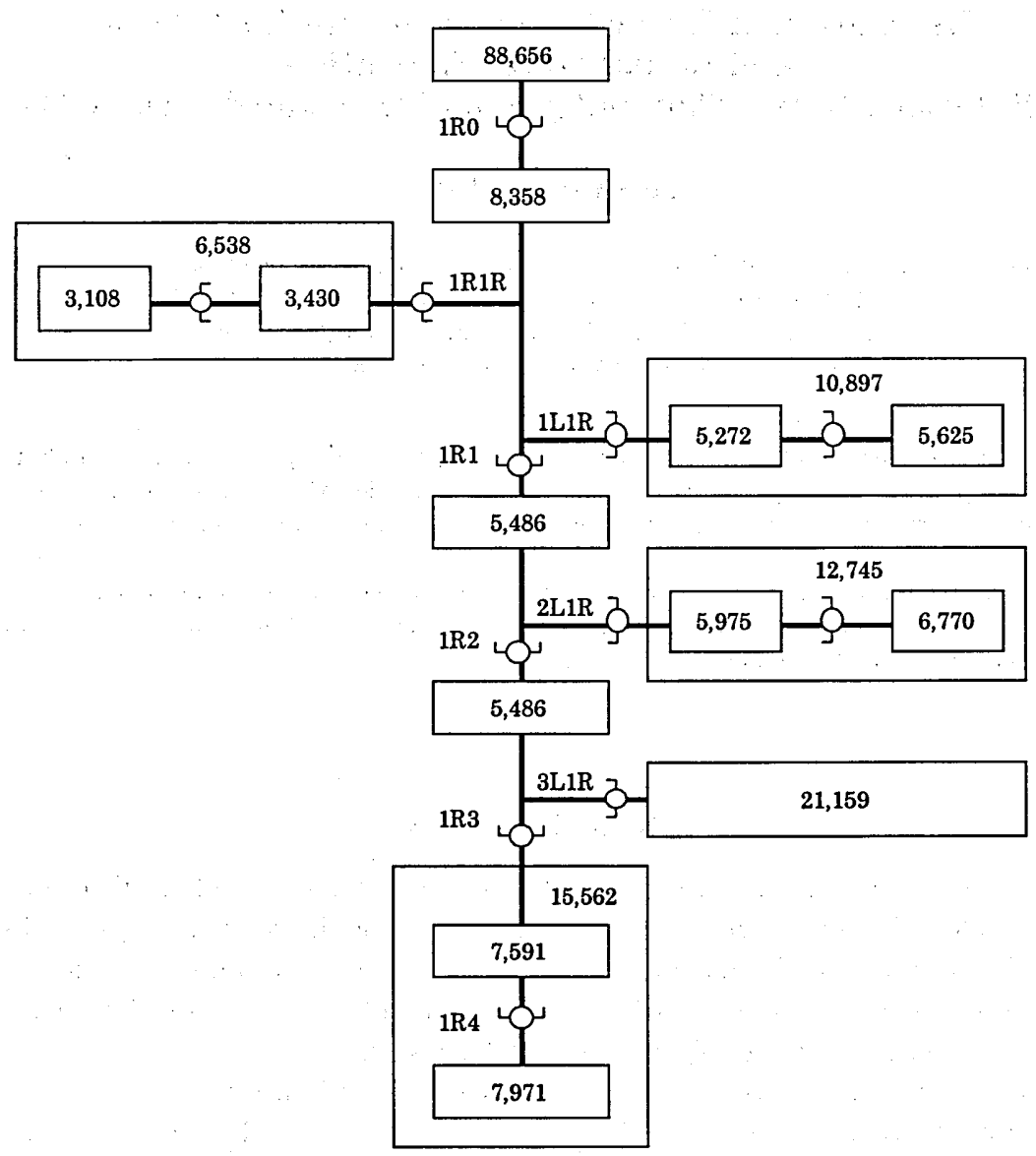

Fig. 1. Command area (rai) of each regulator in Section 1

every command area of the regulator. Section 1 is command area of $1 \mathrm{R}$ main canal, and it has been composed of nine zones. Command area (rai) of each regulator in Section 1 is shown in the block diagram in Fig. 1.

Planting area survey has been made in every zone. Example of result of converting planting area of every zone into planting area of every command area of each regulator is shown at Fig. 2(a) and Fig. 2(b).

\section{ESTIMATION OF GROSS WATER REQUIREMENT}

According to the above-mentioned definition, the estimate of district water requirement is shown by the following equation.

$$
D_{i}=1.6 \sum_{j=1}^{n} A_{i j} \cdot I_{i j} / \eta_{j}
$$




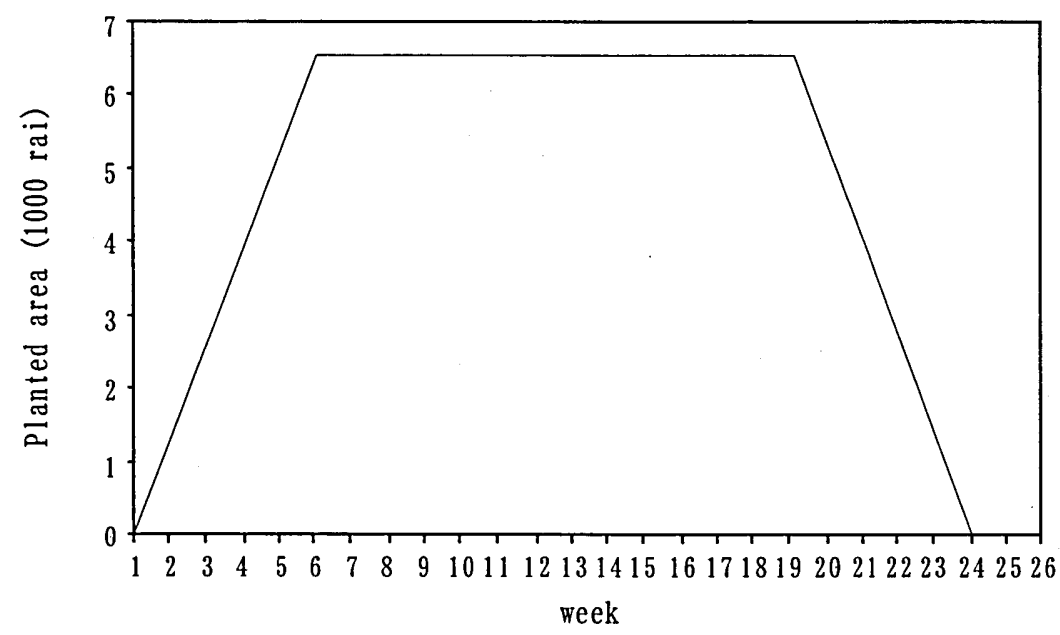

Fig. 2 (a). Change of totaled planted area (1R1R, 1990)

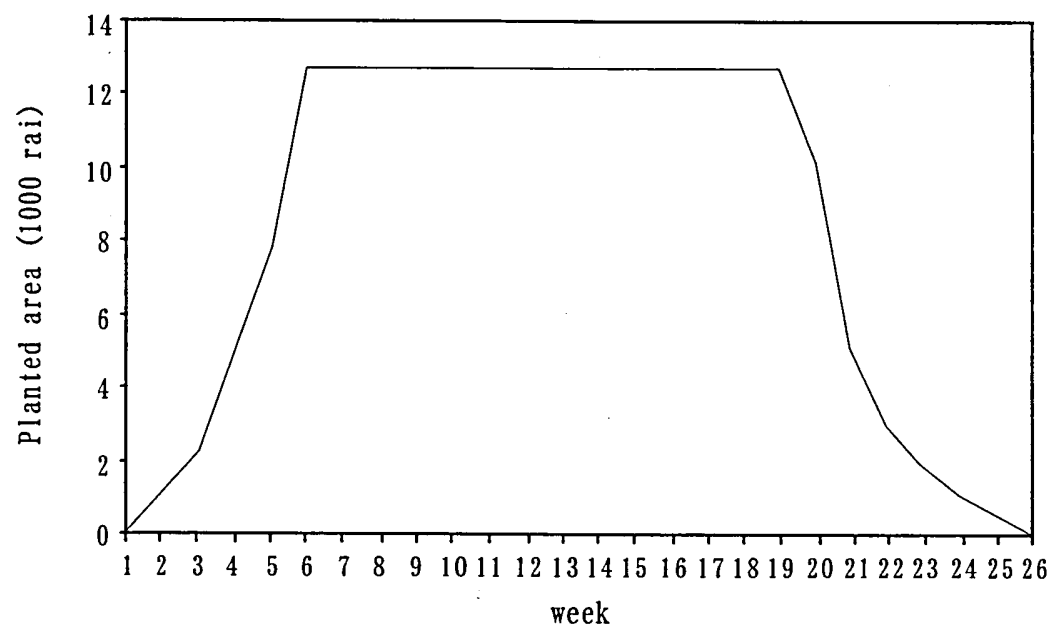

Fig. 2 (b). Change of totaled planted area (2L1R, 1990)

where $i$ : day, $j$ : crop number, $n:$ type number of the crop, $D_{\mathrm{i}}:$ gross water requirement on $\mathrm{i}^{\text {th }}$ day $\left(\mathrm{m}^{3} / \mathrm{d}\right), A_{\mathrm{ij}}$ : planted area of crop $j$ on $\mathrm{i}^{\text {th }}$ day (rai), $I_{\mathrm{ij}}$ : pure irrigation water of crop $j$ on $\mathrm{i}^{\text {th }}$ day $(\mathrm{mm} / \mathrm{d})$ and $\eta_{j}$ : irrigation efficiency of crop $j$. And, constant 1.6 is a coefficient for converting $(\mathrm{rai} \cdot \mathrm{mm} / \mathrm{d})$ into $\left(\mathrm{m}^{3} / \mathrm{d}\right)\left(1 \mathrm{rai} \times 1 \mathrm{~mm} / \mathrm{d}=1600 \mathrm{~m}^{2} \times 10^{-3} \mathrm{~m} / \mathrm{d}=\right.$ $\left.1.6 \mathrm{~m}^{3} / \mathrm{d}\right)$.

It was assumed that the average depth of fish pond was $50 \mathrm{~cm}$ and that the water is changed in every $10 \mathrm{th}$. Therefore, the water of per day $50 \mathrm{~mm}$ was supposed to be sup- 
plied.

The calculation example :

Next table is the data on regulator 1R1R, February 25 th, 1991. On these data, we try to calculate gross water requirement. Still, rainfall in the day is 0 .

Table 1. Calculation example of water requirement (1R1R, Feb. 25th, 1991)

\begin{tabular}{lccccc}
\hline \multirow{2}{*}{ Land Use } & (1) & (2) & (3) & (4) & (5) \\
\cline { 2 - 6 } & Paddy & Upland Crop & Sugarcane & Fruits etc. & Fish pond \\
\hline Planted Area(Rai) & 379 & 128 & 345 & 40 & 32 \\
Epenman & 5.3 & 5.3 & 5.3 & 5.3 & 5.3 \\
Kp(=ET/E) & - & 0.8 & 0.9 & 1.0 & 0.5 \\
Water Req.(I) & 11.0 & 4.2 & 4.8 & 5.3 & 25.2 \\
Irr. Efficiency $(\eta)$ & 1.0 & 1.0 & 1.0 & 1.0 & 1.0 \\
\hline
\end{tabular}

$$
\begin{aligned}
D & =1.6(11 * 379+5.3 * 0.8 * 128+5.3 * 0.9 * 345+5.3 * 1.0 * 40+50.0 * 32) \\
& =1.6(11 * 375+4.2 * 128+4.8 * 345+5.3 * 40+50.0 * 0.32) \\
& =1.6(4125+537.6+1656+212+1600.0) \\
& =1.6 * 8130.6 \\
& =13009\left(\mathrm{~m}^{3} / \mathrm{d}\right)
\end{aligned}
$$

Like this, it is easy to estimate gross water requirement, if we can grasp only the planted area accurately. However, we have to consider irrigation efficiency, so we can expect that upland irrigation efficiency is about 0.6 from the viewpoint of furrow irrigation. If paddy water stored in a canal is used effectively, irrigation efficiency of paddy can be expected to be almost 1.0. Irrigation efficiency as a block which is near for the inlet will be small. It is future problem to clarify this value.

\section{REGULATOR PASSAGE DISCHARGE}

\section{Distinction of flow type}

Regulator is consists of gate and box or pipe. According to the relationship between up and downstream water levels, several flow conditions appear. Therefore, we have to adopt a suitable discharge formula to correspond with each flow condition. Fig. 3 shows various flow conditions in regulator.

\section{Dimensions of Regulators}

Up and downstream water levels, gate opening and the dimensions each regulator are necessary for calculating discharge. Table 2 shows the dimensions of each regulator.

\section{Conversion of discharge $\left(\mathrm{m}^{3} / \mathrm{s}\right)$ to daily discharge $\left(\mathrm{m}^{3} / \mathrm{d}\right)$}

Considering all conditions of the superscription, after calculation of discharge $\left(\mathrm{m}^{3} / \mathrm{s}\right)$ using water level and gate opening data at each time, it is possible to calculate discharge in a day $\left(\mathrm{m}^{3} / \mathrm{d}\right)$ by integrating discharge at each time. We can use Simpson's formula to 
Table 2. Dimensions of Regulators

\begin{tabular}{lccccc}
\hline Location & $\begin{array}{c}\text { The } \\
\text { Number }\end{array}$ & $\begin{array}{c}\text { Size } \\
\text { Width*Height } \\
(\mathrm{m})\end{array}$ & $\begin{array}{c}\text { Length } \\
\text { of Pipe } \\
(\mathrm{m})\end{array}$ & $\begin{array}{c}\text { Max. of } \\
\text { Discharge } \\
\left(\mathrm{m}^{3} / \mathrm{s}\right)\end{array}$ & $\begin{array}{c}\text { Elevation } \\
\text { of Sill } \\
(\mathrm{m})\end{array}$ \\
\hline 1R 0.075 & 1 & $2.50^{*} 2.90$ & & 12.000 & 6.090 \\
1R 13.200 & 1 & $2.00^{*} 2.40$ & & 7.550 & 5.310 \\
1R 17.660 & 2 & $2.00^{*} 2.00$ & 9.5 & 5.440 & 4.561 \\
1R 22.300 & 2 & $2.00^{*} 2.00$ & & 4.270 & 4.410 \\
1R 28.800 & 2 & $1.25^{*} 1.25$ & 5.5 & 2.620 & 3.898 \\
1R 35.325 & 2 & $\phi 1.00$ & 7.0 & 2.060 & 3.080 \\
1R 11.700 & 1 & $\phi 1.00$ & 9.0 & 1.330 & 5.940 \\
1R1R 3.350 & 1 & $\phi 1.00$ & 8.0 & 0.643 & 5.330 \\
1R1R 7.000 & 1 & $\phi 0.50$ & 8.0 & & \\
1R 13.200 & 1 & $1.75^{*} 1.50$ & 13.0 & 2.730 & 5.458 \\
1L1R 3.950 & 2 & $\phi 1.00$ & 7.0 & 2.205 & 5.995 \\
1L1R 7.620 & 1 & $\phi 1.00$ & 8.0 & 1.245 & 5.680 \\
1R 17.650 & 2 & $\phi 1.00$ & 14.0 & 1.547 & 5.345 \\
2L1R 4.300 & 2 & $\phi 1.00$ & 10.0 & 1.280 & 4.770 \\
1R 22.100 & 2 & $\phi 1.00$ & 10.5 & 3.106 & 4.968 \\
\hline
\end{tabular}

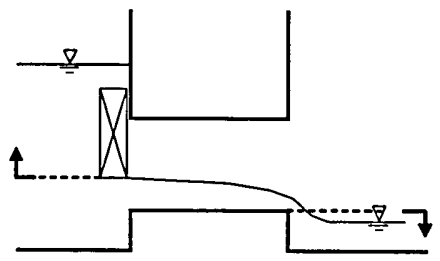

(1) Small Orifice

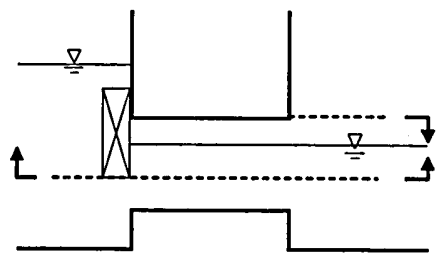

(3) Completely Submerged Orifice

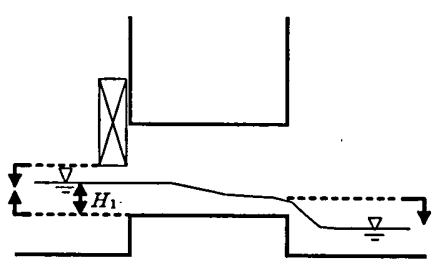

(5) Broad Crested Weir $\left(\triangle H \geqq H_{1} / 3\right)$

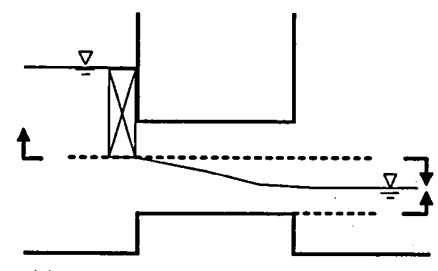

(2) Partially Submerged Orifice
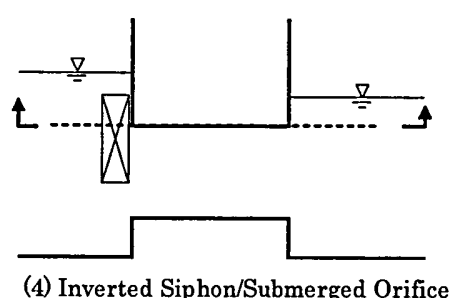

(4) Inverted Siphon/Submerged Orifice

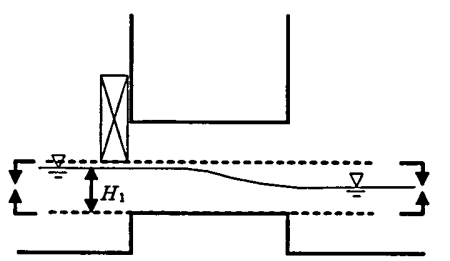

(6) Submerged Weir $\left(\triangle H<H_{1} / 3\right)$

Fig. 3. Various flow conditions in regulator and applicable formulas $\Delta H$ : the difference in water level between up and downstream. $H_{1}$ : overflow depth upstream. 
integrate discharge.

$$
Q=\frac{\Delta t}{3}\left(q_{1}+4 q_{2}+q_{3}\right)
$$

where $q_{1}, q_{2}$ and $q_{3}$ are a series of discharge. $\Delta t$ is a time interval, and it is 3 hours in this case. There are 5 measured data, which are taken data $6,9,12,15$ and 18 o'clock. By interpolation between yesterday's and tomorrow's data, it is possible to calculate discharge at $0,3,21,24$ o'clock.

\section{WATER DEMAND AND ACTUAL WATER ALLOCATION}

Referring to command area of $1 \mathrm{R} 1 \mathrm{R}$ and $2 \mathrm{~L} 1 \mathrm{R}$, the comparison between water demand by the simulation and actual water allocation is shown in Fig. 4(a) and Fig. 4(b). In these figures, July-October is a rainy season, and November -December is the dry season. Only the paddy rice is almost cultivated in Section 1.

We adopted intermittent irrigation system as paddy field irrigation system in the simulation of Fig. 4(a) and Fig. 4(b). In this district, this system is general.

According to Fig. 4, simulation and actual condition agree almost by August-October. In Fig. 4, there is the slippage in which some between simulation and actual condition is time-related in August-September, and it agrees with averagely observing, almost. In short, the supply shortfall in August seems to have been solved in September.

In Fig. 4(a) and Fig. 4(b), there is actual water supply after the middle of month November, but water demand by the simulation becomes 0 . Though the cultivation of the field crop is carried out, after the paddy rice is harvested, actually, it is a cause that the data of the planted area is insufficient.

And, actual water supply surpasses a water demand by the simulation in both of Fig. 4(a) and Fig. 4(b) by July the middle of month. It is because it is changed to a water demand generation from the planting start in the simulation, in spite of taking water from the stage of puddling actually. Then, considering this fact, by assuming that the planting time was made early week, the simulation was carried out. The result is shown at Fig. 5(a) and Fig. 5(b). According to Fig. 5(a), there is the coincidence in which water demand by the simulation and actual water supply are good in July. According to Fig. 5(b), the time-related slippage was solved in July, but water demand by the simulation increased from actual water supply.

Generally, diversion requirement for paddy area is shown by the following equation.

(Diversion requirement for paddy area $)=($ Net water requirement $)$

$+($ Conveyance loss $)+($ Delivery water requirement) - (Reuse of irrigation water)

Water demand by present simulation and actual water supply agree almost. It is indicated that (water conveyance loss + delivery water requirement) is almost equal to reuse water for this fact. Return flow was $10-20 \%$ of paddy field water requirement from the observation result of paddy field percolation of previous report. It becomes $10-20 \%$ also reuse ratio return flow using ratio $100 \%$ reuse water assume.

In this district, the weir is established at the drainage canal end, and by piling sand- 


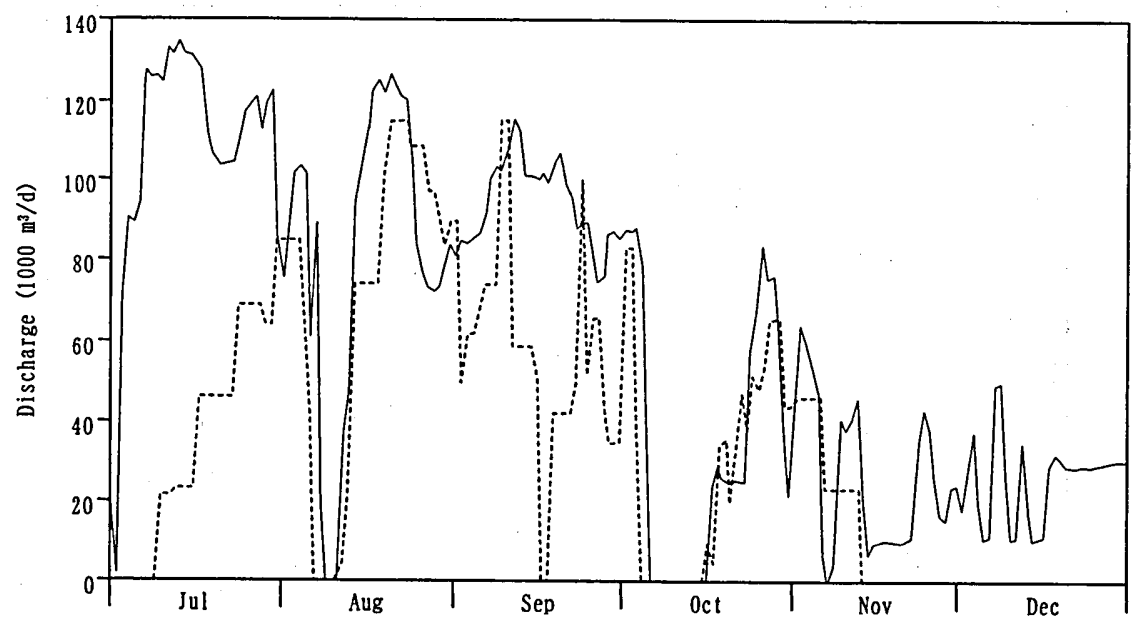

Fig. 4 (a). Water demand by simulation and actual water allocation (1R1R, 1990) (solid line : Actual water supply, broken line : Simulated water supply)

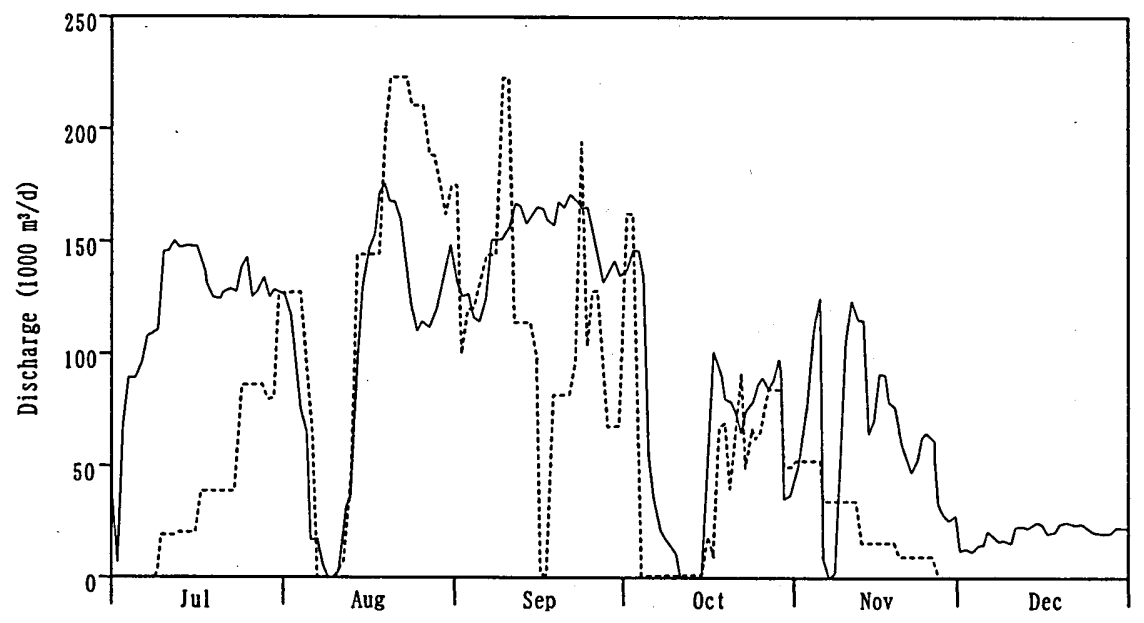

Fig. 4 (b). Water demand by simulation and actual water allocation (2L1R, 1990) (solid line : Actual water supply, broken line : Simulated water supply)

bag, it would not flow in the downstream, it is stored in the drainage canal, and in the drainage canal side paddy field, reuse of water of taking water from the drainage canal has been made. The result that water demand and water supply are almost equal is an appropriate result, when that advanced reuse of irrigation water has been made is considered. And, the simulation can be also called considerably reproducing the actual condition well. 


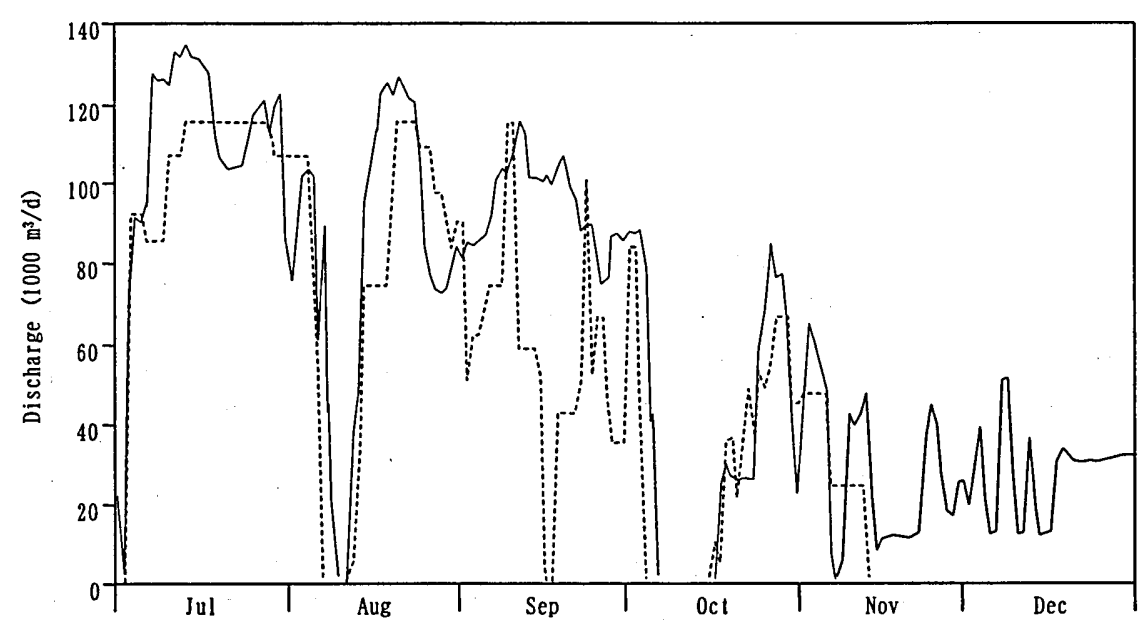

Fig. 5 (a). Water demand by simulation considering paddling season and actual water allocation (1R1R, 1990) (solid line : Actual water supply, broken line : Simulated water supply)

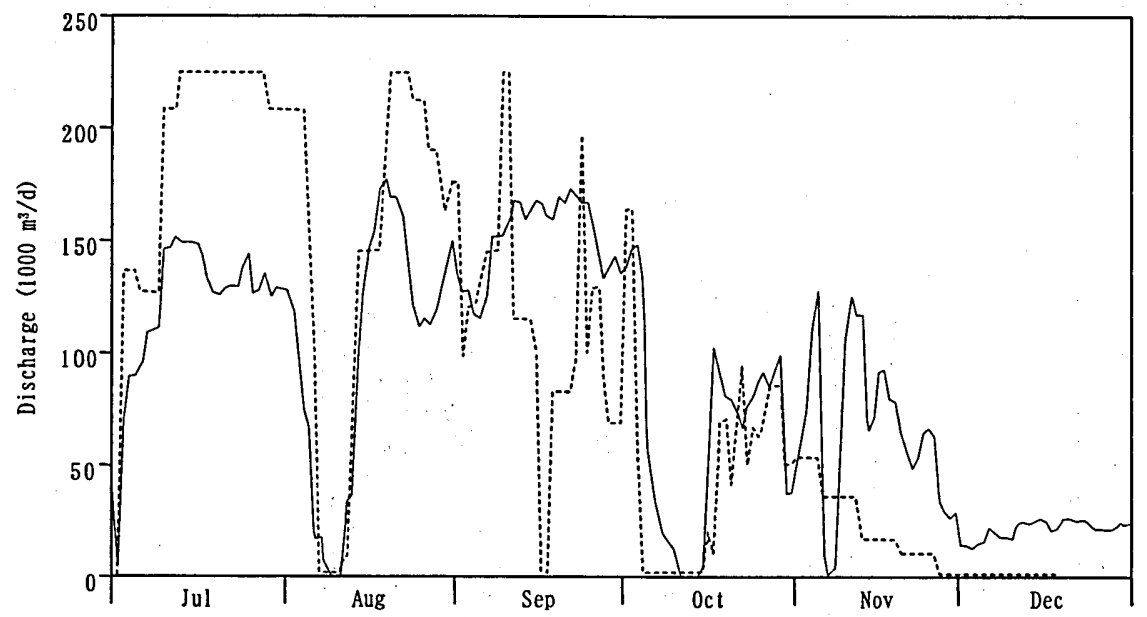

Fig. 5 (b). Water demand by simulation considering paddling season and actual water allocation (2L1R, 1990) (solid line : Actual water supply, broken line : Simulated water supply)

\section{CONCLUSION}

Estimation technique of gross water requirement and calculation technique of actual water supply were established. That reuse of water ratio was $10-20 \%$ by comparing a 
water demand by the simulation with actual water supply, almost clarified.

And, that developed gross water requirement estimation model had the good reproducibility clarified.

It is important to raise the accuracy of the planted area of each cultivated crop in the water requirement calculation in the district where the cultivated crop changes.

\section{REFERENCES}

Royal Irrigation Department 1990 Crop Coefficient and Pan Coefficient (Thailand)

Testuro Fukuda 2005 Estimation model of water requirement in farmland-Referring to the Thailand gravity irrigation district (1)-, J. Fac. Agr., Kyushu Univ., 50(2) (in press)

Testuro Fukuda 2005 Actual Water Consumption and Water Management in Paddy Field-Referring to the Thailand gravity irrigation district (2)-,J. Fac. Agr., Kyushu Univ., 50(2) (in press)

Toshisuke Maruyama 1995 New edition irrigation and drainage, Yokendo 